\title{
HOW TO HELP STUDEn TS REACH THEIR STEM POTENTIAL
}

\author{
HAVING A LOWER INCOME CAN MAKE THE STUDENT EXPERIENCE \\ MUCH MORE CHALLENGING, LEADING TO GREATER DROP-OUT \\ RATES AND HIGHER LEVELS OF STUDENT DISSATISFACTION. DR \\ NICK FLYNN, OF WEST TEXAS A\&M UNIVERSITY IN THE US, WANTS \\ TO ADDRESS THIS AND IS LEADING A NEW PROJECT THAT AIMS TO \\ SUPPORT STUDENTS BOTH FINANCIALLY AND WITHIN THEIR STUDIES
}

\section{GLOSSARY}

FACULTY - a group of related university departments and the members of staff within them

GATEWAY COURSE - an introductory course to a particular subject area that means the student can go on to study other courses within the subject area

\section{HIGH-IMPACT PRACTICES - core} activities that lead to greater student success in college, such as internships, research projects and learning communities

MENTORING - advising or training someone, usually one-on-one

PEER - a person at a similar stage in life to another, such as a friend or classmate
"While I was serving as department head, I realised that some students were working 30 hours or more every week just to survive and pay all of their educational expenses," says $\mathrm{Dr}$ Nick Flynn. "I also realised that our students needed additional help in developing leadership and career soft skills." Nick, a professor of biochemistry at West Texas A\&M University in the US, witnessed first-hand the challenges that students faced. This motivated him to take the lead on a new programme aimed to help low-income students reach success in STEM careers, through financial support, developing their leadership skills, and updating the science courses that the college provides.

\section{THE PROJECT}

Nick's project is not just about helping students financially, though it does do this through providing scholarships for highachieving students between 2019 and 2023. It also includes mentoring, career skill development and leadership training, all of which are known to aid students' chances of success both within their course and later in their career. The project also involves a redesign of six first-year science courses, to make them more accessible and relevant. These redesigns were carried out by three co-principal investigators on the project: $\mathrm{Dr}$ Greg McGovern redesigned the two chemistry labs, Dr Christopher Baird redesigned the two physics labs and Dr Donna Byers revised the two biology lectures. These redesigns were based on discipline-specific initiatives and guidance from national discipline organisations.

\section{Nick secured funding for this project} through the National Science Foundation's Scholarships in STEM (S-STEM) programme, which awarded his college a grant of almost $\$ 1$ million (Award \#1833499). The project aims to increase retention and graduation rates of low-income, academically-talented students, increase student success in gateway courses, and increase student engagement and participation in high-impact practices.

\section{MENTORING}

"We provide peer mentoring, faculty mentoring and college success mentoring for this programme," says Nick. "Mentoring activities include goal setting, the peer review process and personalised career guidance." Mentors can come from various sources and all have their own role to play in improving students' experience and chances of success. 



\section{ABOUT BIOCHEMISTRY}

Nick is now a professor of biochemistry, though his work has taken him across many disciplines. He explains more about his career:

WHAT COLLABORATIONS HAS YOUR CAREER INVOLVED?

I've collaborated with a variety of sectors, such as the brewing industry, agricultural management, government laboratories, food producers, the chemical industry and industrial safety managers. Biochemistry offers a wealth of career opportunities due to the interdisciplinary nature of the field.

WHAT INTERDISCIPLINARY WORK HAS YOUR WORK INVOLVED?

Lots! I led the Department of Mathematics, Chemistry \& Physics, which is about as interdisciplinary as you can get! As other examples, the chemistry and physics departments share some facilities; we have run outreach Science Days incorporating biology, physics, chemistry and biochemistry; and visits to a local honey farm show how closely chemistry and agriculture are linked. These are just a few examples - in this modern age, an interdisciplinary approach is always a good thing, since it allows you to draw from the strengths of each discipline.

\section{WHAT DO YOU FIND REWARDING AND CHALLENGING ABOUT}

\section{CHEMISTRY?}

Chemistry allows you to come up with explanations for things that we do not currently understand. On the other hand, teaching chemistry can sometimes be a challenge, since some students do not understand why it is required for their degree! My greatest reward as a teacher is some of my student evaluation comments where they recognise my passion for chemistry and my willingness to go to great lengths to get them to appreciate how much chemistry can affect and improve the quality of their life. My greatest challenge has been helping a student realise that the tools they learn in chemistry can be applied in their everyday life. For example, I use doubling or tripling a cookie recipe to help students see how dimensional analysis can be used to identify how much of each particular ingredient they need.

\section{WHAT IS THE ROLE OF \\ STORYTELLING IN SCIENTIFIC \\ EDUCATION?}

Storytelling is an excellent way to engage students in all types of subject matter. Some of the material we teach in science can be quite dry, so adding a personal touch can make it much more enjoyable. I've worked with the history department to give a talk on science through the ages with two physics colleagues - to tell the narratives behind the scientific achievements. That's another great example of different disciplines being intrinsically linked. Storytelling can also help students gain appreciation for concepts we teach such as the fact that even weak acids, such as hydrofluoric acid, need to be treated with respect. In fact, I use an old episode of the TV series ER regarding this very acid to explain the concepts of electronegativity and acid strength to my students. I have had senior level students tell me that they still remember that particular discussion in class.
HOW DOES YOUR PASSION FOR BIOCHEMISTRY EXTEND INTO YOUR FREE TIME?

I love homebrewing, particularly the community it forms. We have the opportunity to learn so much from each other and to share our knowledge and passion. From a chemistry perspective, I am fascinated by the ageing process of beer - sometimes it is a good thing, and sometimes it is not! Recently, I gave a webinar to the American Chemical Society entitled: 'Chemists Make the Best Homebrewers', where we discussed methods of homebrewing and how chemical educators can use brewing concepts in their courses.

\section{WHAT WILL BE THE KEY ISSUES FOR THE NEXT GENERATION OF \\ BIOCHEMISTS}

Water purity and industrial safety are set to become major challenges. Food production, as well as environmental protection and clean-up, will also be ever-more important issues into the future. The wonderful thing about being a scientist is having the opportunity to make things better for the entire world.

\section{DOES THE WEST TEXAS A\&M} UNIVERSITY OFFER ANY PUBLIC OUTREACH SCHEMES FOR YOUNG PEOPLE?

We collaborate with the Don Harrington Discovery Center, a local science museum, to provide activities for the ACS National Chemistry Week and Chemists Celebrate Earth Week. We also invite speakers from many walks of life, such as industry, weather and environmental sciences.

\section{EXPLORE A CAREER In BIOCHEMISTRY}

- The American Chemical Society (ACS) offers educational resources and careers advice: www.acs.org

- According to PayScale, the average salary for a biochemist in the US is around $\$ 62 k$. Like most STEM careers, industry will tend to pay higher than academia.

\section{PATHWAY FROM SCHOOL TO BIOCHEMIST}

Many courses require qualifications in two or more sciences, especially chemistry and mathematics. Nick says a strong mathematical foundation is essential and also advocates taking English or public speaking to learn how to express your ideas clearly.

- Biochemistry can be an undergraduate qualification in itself but, more often, degrees in chemistry or biology will allow specialisation in biochemistry after two or three years. Other degrees, such as natural sciences or medicine, can also lead to a career in biochemistry. 


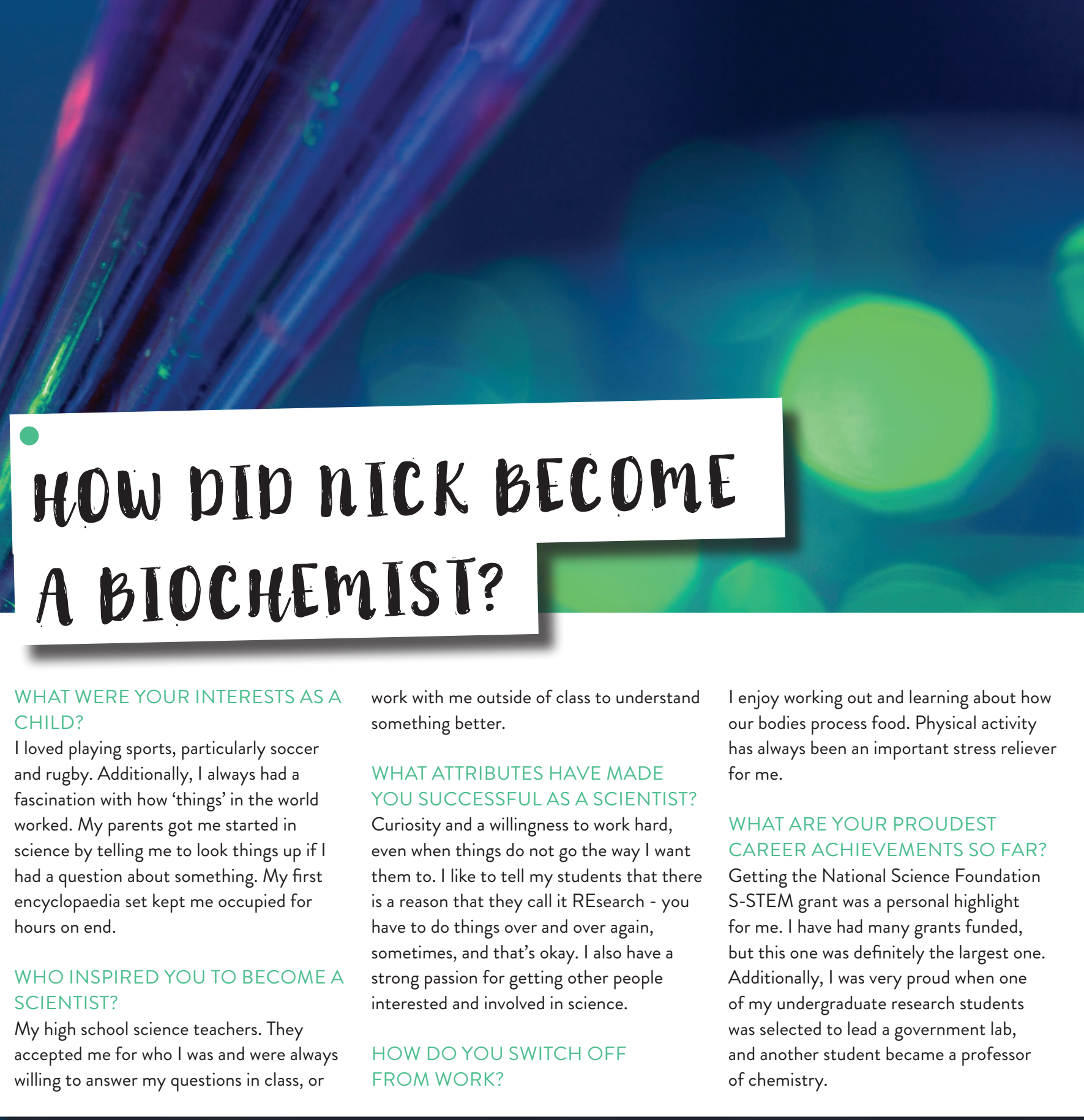

\section{nICKS' TOP TIPS}

O1 Always be open to new opportunities and experiences.

02 If you find yourself dissatisfied, think about what is actually important to you and what would get you excited about work or study. This will help you identify where you should focus to reach your goals.

O3 Learn how to express yourself, both when writing and when speaking. Many times, I have seen a great, welldesigned study compromised by a poor presentation.

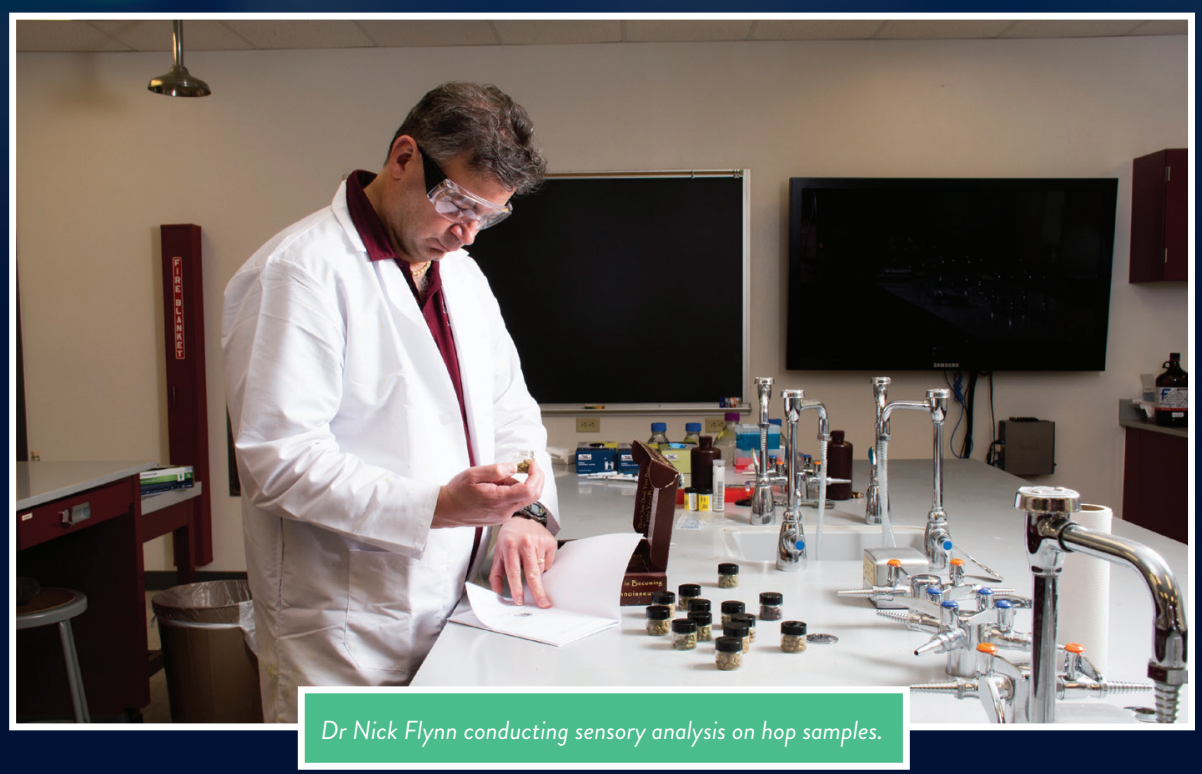

